\title{
KECERDASAN SPASIAL DALAM MEMAHAMI TRIMATRA: STUDI STRATEGI PEMBELAJARAN MATA KULIAH NIRMANA II (TRIMATRA)
}

\author{
Ernawati \\ Prodi Desain Komunikasi Visual, Universitas Maarif Hasyim Latif \\ Sidoarjo, Indonesia \\ e-mail: ernawati@dosen.umaha.ac.id
}

\begin{tabular}{|l|c|c|}
\hline CC) (1) & $\begin{array}{l}\text { This is an open-access article under the CC BY-SA license. } \\
\text { Copyright }(2) 2020 \text { by Author. Published by Universitas Pendidikan Ganesha. }\end{array}$ \\
\hline RY SA & Accepted : June, 2020 & Published : June, 2020 \\
\hline
\end{tabular}

\begin{abstract}
ABSTRAK
Tujuan penelitian ini adalah berdiskusi tentang strategi pembelajaran yang optimal sehingga tercapai tujuan sesuai dengan visi dan misi mata kuliah Nirmana II (Trimatra) yang tercantum pada kurikulum. Metode pada penelitian ini menerapkan metode tindakan kelas dengan pendekatan model PTK (Penelitian Tindakan Kelas) dari Kurt Lewin, yang fokus mengeksplorasi peran strategi pengajaran kecerdasan spasial terhadap proses pengembangan kreativitas mahasiswa dalam pembelajaran Nirmana II. Mahasiswa dalam bidang seni dan desain erat dengan kreativitas dan kepekaan, tentu perlu persiapan dalam memahami tata kelola unsur-unsur desain. Kecerdasan spasial, yaitu kemampuan memvisualisasi ide-ide yang berkenaan dengan ruang dan tempat. Kecerdasan spasial merupakan kecerdasan yang dimiliki oleh sebagian besar mahasiswa seni rupa dan desain. Nirmana II (Trimatra) mempersiapkan mahasiswa untuk memiliki kepekaan rasa, ketajaman analisis visual dan pemahaman mendalam terhadap ilmu dasar seni rupa dan desain. Nirmana II berpengaruh terhadap mata kuliah lainnya yang berhubungan dengan teori maupun praktik desain komunikasi visual. Modifikasi strategi pembelajaran Nirmana II (Trimatra) dengan kontekstual (visual-spasial) dan evaluasi penilaian mampu menjadi poin penting dalam mengatur suasana kelas yang kondusif, meningkatkan kualitas semangat belajar dan meningkatkan pemahaman serta kreativitas mahasiswa untuk berkarya. Proses analisis dilakukan melalui pengumpulan data yang bersifat terukur
\end{abstract}

Kata-kata kunci : Nirmana II, spasial, strategi pembelajaran, visual

\section{ABSTRACT}

The purpose of this study is to discuss optimal learning strategies so that the objective is achieved under the vision and mission of Nirmana II (Trimatra) courses listed in the curriculum. The method in this study applied classroom action research (PTK) with the research approach from Kurt Lewin, which aimed to explore the strategic roles of the spatial intelligence learning toward the process of students' creativity development in Nirmala learning. Arts and design students have a close relationship with creativity and sensitivity in which they need preparation in understanding the governance of design elements. Spatial intelligence is an ability to visualize the ideas relating to space and place. Spatial intelligence is an intelligence possessed by most fine art and design students. Nirmana II (Trimatra) prepares students to have a sense of taste, sharpness of visual analysis, and a deep understanding of the basic fine arts and design. Nirmana influences other courses relating to the theory and practice of visual communication design. 
Modification of the Nirmana II learning strategy (Trimatra) with contextual (visual-spatial) and evaluation assessment can be important points in managing a conducive classroom atmosphere, improving the quality of enthusiasm for learning, and increasing students' understanding and creativity to work. The analysis process is done by collecting data that is measurable.

Keywords: Nirmana II, spatial, learning strategies, visual

\section{PENDAHULUAN}

Karya hasil cipta manusia diharapkan memiliki nilai keindahan dari penciptanya. Dalam mencapai hal tersebut, dibutuhkan keilmuan tentang pengorganisasian unsur rupa dan desain yang tepat. Rupa merupakan wujud visual yang dapat terlihat oleh indera mata. Ilmu tata rupa diperlukan sebagai ilmu pijakan guna mempelajari cara penyusunan atau penataan unsur visual/rupa dan desain yang tampak terlihat oleh mata guna memperoleh nilai artistik atau nilai keindahan. Salah satu teori yang perlu dikuasai sebagai pengantar pemahaman dalam dunia visual yaitu Nirmana.

Dalam kurikulum pada Program Studi Desain Komunikasi Visual, mata kuliah Nirmana merupakan mata kuliah yang ditempatkan pada awal semester, yaitu pada semester satu dengan mata kuliah Nirmana I (dua dimensi) dan semester kedua yaitu Nirmana II (trimatra). Nirmana merupakan salah satu mata kuliah yang memiliki posisi penting, karena sebagai mata kuliah dasar dalam kemampuan seni rupa dan desain. Nirmana selain sebagai langkah awal untuk mengasah kreativitas mahasiswa dalam menciptakan karya visual baik seni rupa maupun desain, Nirmana juga sebagai bidang ilmu yang berkontribusi sebagai wadah pengetahuan dalam upaya memahami dasar-dasar seni rupa dan desain. Mata kuliah ini termasuk sebagai mata kuliah yang wajib ditempuh oleh mahasiswa Program Seni Rupa maupun Desain, salah satunya oleh mahasiswa Program Studi Desain Komunikasi Visual di Universitas Maarif Hasyim Latif.

Nirmana II (Trimatra) berhubungan dengan penyusunan dan pengorganisasian unsur-unsur seni rupa atau desain yang diwujudkan dalam wujud nyata berupa benda/karya tiga dimensi. Mengingat peran penting mata kuliah ini, tentunya perlu strategi supaya pembelajaran berjalan efektif dan efisien serta optimal. Strategi pembelajaran mencakup proses belajar sampai ketercapaian hasil belajar melalui evaluasi hasil belajar melalui penilaian, tentunya dengan metode dan teknik yang telah ditentukan oleh dosen.

Ilmu mengenai penyusunan/penataan rupa dan desain dianggap diperlukan bahkan berperan penting, dikarenakan dalam kehidupan sehari-hari manusia tentunya melibatkan hal yang berhubungan dengan keindahan/nilai artistik, baik sebagai pengguna, pencipta maupun pengamat. Ilmu penyusunan/penataan rupa dan desain perlu diajarkan (Nirmana) sebagai dasar metode mencipta karya seni dan desain lebih lanjut bagi seniman atau desainer, supaya dapat menciptakan karya seni dan merancang desain yang berkualitas dan bermutu berdasarkan keilmuan.

Mempelajari penyusunan/penataan rupa dan desain (Nirmana) akan lebih baik jika menyeimbangkan antara penguasaan teori dengan pengaplikasiannya melalui praktik dengan melibatkan pemikiran dan perasaan. Kepekaan terhadap pengelolaan mengorganisasikan elemen visual berkaitan erat dengan kecerdasan spasial, yaitu kemampuan menyajikan visual ide berdasarkan pada ruang dan tempat. Kemampuan kecerdasan spasial perlu diasah guna menguasai esensi dan makna dari matakuliah 
Nirmana II (Trimatra), sehingga tujuan pembelajaran dapat tercapai. Dalam hubungannya antara kecerdasan spasial dengan Nirmana, (Amstrong, 2013: 7) mengemukakan bahwa kecerdasan spasial melibatkan kepekaan terhadap warna, garis, bidang, bentuk, ruang dan hubungan unsur-unsur rupa tersebut. Dalam upaya memperbaiki siklus sebelumnya, pada tahap siklus berikutnya ditekankan pada kecerdasan kecerdasan spasial. Kecerdasan spasial merupakan salah satu bagian dari kecerdasan majemuk yang dimiliki manusia. Gardner mengemukakan bahwa kecerdasan spasial merupakan kemampuan mempersepsi dunia spasial-visual secara akurat sekaligus mampu mentransformasikannya (Armstrong, 2013). Level kecerdasan spasial terjadi ketika mahasiswa melakukan pencerapan dan penerapan (aplikasi). Mahasiswa mempersepsi visual dengan melatih kepekaan pada unsur rupa dan desain serta relasi atau hubungan antar unsur atau elemen visual. Dimensi yang dijadikan perubahan strategi pembelajaran ditingkatkan pada aspek dimensi pemahaman secara teori dan dimensi penerapan pemahaman teori dalam pengaplikasiannya dalam karya Nirmana II (Trimatra). Ada lima upaya dalam strategi pengajaran kecerdasan spasial yang coba dilaksanakan dalam proses pembelajaran. Lima upaya tersebut berdasarkan kepada strategi spasial yang dikemukakan Armstrong (2013: 86), kelima strategi tersebut yaitu: visualisasi, tanda-tanda berwarna-warni, gambar metafora, sketsa ide, dan simbol-simbol gambar.

Berdasarkan keilmuan tersebut penerapan strategi kecerdasan spasial dalam perubahan pembelajaran mata kuliah Nirmana guna meningkatkan kreativitas mahasiswa cukup relevan dan efektif. Dengan mempelajari Nirmana berdasarkan strategi pembelajaran yang efektif diharapkan mahasiswa memiliki kemampuan untuk mengkaji dan menciptakan karya seni rupa dan desain. Dengan berbagai latihan olah cipta dan olah rasa seseorang akan terbiasa sehingga secara otomatis memiliki kesadaran artistik terhadap dunia visual dan desain baik sebagai pencipta maupun pengkaji karya dengan ketajaman visual yang terus meningkat seiring dengan pengalaman/latihan yang dilakukan.

Mempelajari Nirmana (penyusunan/penataan rupa dan desain) dimaksudkan supaya seseorang dapat menghargai/mengapresiasi karya orang lain dan menciptakan karya yang estetik berdasarkan prinsip penyusunan unsur visual. Hal tersebut tidak terlepas dari tujuan mempelajari Nirmana (penyusunan/penataan rupa dan desain) yaitu melatih kepekaan artistik, melatih keterampilan teknis, dan melatih pemahaman bahasa rupa. Karya seni dan desain tidak hanya sekedar indah namun lebih jauh lagi harus memiliki pesan atau misi tertentu yang disampaikan kepada khalayak ramai. Namun pada pembahasan Nirmana hanya sebatas unsur-unsur seni rupa dan desain serta prinsip penyusunan unsur rupa dan desain. Lebih jauh lagi, dengan diadakannya analisis pendataan pada Penelitian Tindakan Kelas (PTK) diharapkan dapat mengeksplorasi peran strategi pengajaran kecerdasan spasial terhadap proses pengembangan kreativitas mahasiswa dalam pembelajaran Nirmana atau Trimatra.

\section{METODE}

Metode yang digunakan pada penelitian ini metode Penelitian Tindakan Kelas (PTK atau Penelitian Tindakan Kelas) dengan berusaha mengembangkan suasana belajar yang kondusif dan meningkatkan kualitas ke arah kondisi yang diharapkan. Penelitian ini dilaksanakan guna meningkatkan kemampuan mahasiswa tentang Nirmana II (Trimatra), baik dari segi pengetahuan maupun praktik berkarya. 
Penelitian ini difokuskan pada upaya meningkatkan kemampuan mahasiswa dalam mempresentasikan, mengapresiasi dan menciptakan karya trimatra berdasarkan pengetahuan (aspek kognitif) atau standar keilmuan dasar rupa dan desain yaitu Nirmana. Mahasiswa mampu memahami korelasi antara konsep keilmuan dengan perwujudan karya. Perkembangan keterampilan mahasiswa diharapkan terjadi setelah dosen menyusun dan melaksanakan pembelajaran dengan pendekatan praktik berkarya berbasis kontekstual. Kemampuan mahasiswa diketahui setelah melalui proses penilaian terhadap karya hasil belajar mahasiswa. Selain itu, kemampuan mahasiswa mempresentasikan dan menganalisis karya masuk ke dalam kategori alat ukur kemampuan mahasiswa.

Penelitian Tindakan Kelas ini berawal dari permasalahan minimnya pengetahuan tentang Nirmana dan ketidakmampuan beberapa mahasiswa dalam mendeskripsikan karya tugas I tentang Nirmana garis ketika dihubungkan dengan teori dasar rupa dan desain. Berkaitan dengan tindakan kelas yang dipilih difokuskan pada strategi pembelajaran yang peneliti laksanakan di kelas.

Penelitian Tindakan Kelas ini dilaksanakan dengan pendekatan berdasarkan model PTK dari Kurt Lewin, yang terdiri atas empat langkah perlakuan. Langkah pertama, proses perencanaaan, guna mengembangkan dan memperbaiki situasi yang telah terjadi. Langkah kedua, melaksanakan aksi dan tindakan sebagai penjelasan dari proses perencanaan. Langkah ketiga, proses observasi yaitu dosen sebagai peneliti mengamati dampak yang terjadi berdasarkan situasi yang disampaikan dalam konteks kejadian. Langkah keempat, yaitu refleksi untuk dapat melakukan analisis, sintesis dan interpretasi terhadap seluruh proses, baik perencanaan maupun tindakan sehingga dapat ditarik kesimpulan yang cenderung akurat dan tajam. Meskipun prosedur dilaksanakan berdasarkan langkah-langkah tersebut, namun keempat langkah tidak dapat terpisahkan, karena berfungsi dalam kegiatan siklus yang berperan secara berkesinambungan.

\section{HASIL DAN PEMBAHASAN}

Penelitian ini dilaksanakan melalui proses perencanaan, tindakan, observasi dan refleksi sebagai siklus pertama (siklus I). Selanjutnya siklus berikutnya ditentukan dari hasil refleksi siklus I, dengan mengupayakan perbaikan mulai dari perencanaan dan pencarian solusi pemecahan masalah dari hasil evaluasi masalah yang terjadi pada siklus I. Prosedur tersebut dilaksanakan secara berlanjut, menyesuaikan dengan situasi pembelajaran sehingga tercapai peningkatan hasil belajar dari tindakan sebelumnya, yang dapat terlihat dari evaluasi penilaian hasil belajar mahasiswa.

\section{Perencanaan dan Pelaksanaan Tindakan}

Perencanaan mulai dilaksanakan ketika ditemukannya permasalahan pada situasi pembelajaran sampai pada dilaksanakannya kegiatan berupa tindakan. Langkah kegiatan dimulai ketika ditemukannya ketidakseimbangan antara kemampuan pemahaman materi/teori keilmuan desain tentang Nirmana dengan kemampuan praktik mewujudkan karya pada kegiatan perkuliahan. Terdapat jarak antara teori dan hasil karya praktik yang dihasilkan oleh mahasiswa pada karya Nirmana. Hal tersebut makin terlihat ketika mahasiswa mempresentasikan karya komposisi garis yang merupakan tugas praktik I, beberapa mahasiswa kurang menguasai cara memaparkan dan mengapresiasi karya. Langkah berikutnya yang diambil merumuskan kembali skenario pembelajaran yang tertuang dalam RPS (Rencana Pembelajaran Semester), dengan menambahkan 
penguasaan teori tentang unsur dan prinsip desain dengan diskusi dan penugasan secara kelompok. Menambahkan beberapa aspek dalam bahan ajar mata kuliah Nirmana, dengan proses pemaparan dan apresiasi karya sebagai wujud pendekatan kontekstual. Merumuskan aspek penilaian sebagai bahan evaluasi yang mampu menjadi motivasi mahasiswa dalam berkarya Nirmana II (Trimatra). Setelah proses tersebut dilakukan, dilanjutkan dengan melakukan sosialisasi kepada mahasiswa, mengenai pentingnya menambah wawasan kemampuan untuk menguasai teori, praktik dan kemampuan untuk mempresentasikan serta mengapresiasi karya.

Tahap berikutnya yaitu tindakan dengan melakukan penambahan perlakuan pada materi ajar yang disusun. Pelaksanaan tindakan tidak lepas dari skenario pembelajaran yang telah disusun dan dikembangkan dalam RPS baik perlakuan, penugasan maupun evaluasi pembelajaran. Pada saat tindakan kelas dalam penelitian, dilaksanakan observasi dan pengamatan instrumen penelitian yang telah disiapkan. Selain dicatat dalam bentuk catatan lapangan, permasalahan dapat terlihat dari lembar tugas mahasiswa yang telah diberi identitas dan urutan karya berupa revisi hasil evaluasi seperti kritik dan saran dari pengajar.

Hasil observasi dan kumpulan data dipakai sebagai bahan analisis untuk perbaikan pada tindakan siklus berikutnya. Keberhasilan atas tindakan sebelumnya dapat terus dilanjutkan, sementara permasalahan yang timbul sebagai bahan evaluasi untuk diadakan perubahan dalam tindakan di siklus berikutnya.

\section{Perkuliahan Nirmana II (Trimatra) pada Program Studi Desain Komunikasi Visual}

Program Studi Desain Komunikasi Visual (DKV), merupakan prodi yang cukup relevan dengan situasi sekarang yang berbasis teknologi industri, sehingga akan menonjol secara teknis. Hal ini dapat menjadi cara pandang segelintir mahasiswa yang menganggap hanya mata kuliah yang menggunakan teknologi digital saja yang berperan dan berguna di kehidupan nyata, sehingga kesadaran akan pentingnya mata kuliah dasar yang bersifat konsep seperti Nirmana II (Trimatra) yang masuk ke dalam bentuk nyata tiga dimensi terkadang luput dari perhatian. Keadaan tersebut tidak mewakili kondisi kelas, karena kenyataannya masih banyak mahasiswa yang mengikuti mata kuliah ini dengan serius, asyik dan santai dengan rasa ingin tahu yang cukup tinggi. Hal ini terlihat dari cara mereka mengikuti proses pembelajaran, keaktifan di kelas dan karya yang diciptakan. Mahasiswa yang aktif juga melanjutkan belajar di luar kelas dengan konsultasi dan bimbingan karya baik secara langsung maupun melalui komunikasi di media online.

Pada proses perkuliahan Nirmana II (Trimatra), mahasiswa ditugaskan untuk fokus menyusun dan mengorganisasikan unsur-unsur desain dengan menerapkan prinsip penyusunan desain. Karena menekankan pada citra visual atau mengkomunikasikan visual karya diarahkan dengan kreatif untuk memiliki ketelitian dalam memilih media dan menguasai karakter serta sifat media yang dipakai. Motivasi untuk berani menggunakan new media juga ditanamkan guna menumbuhkan jiwa kreativitas mahasiswa. Wujud dan bentuk karya Nirmana yang dihadirkan menjadi penting bagi Prodi Desain Komunikasi Visual mengingat lulusan prodi ini perlu memahami secara teori dan praktik tentang desain baik karya yang bersifat dua dimensi maupun tiga dimensi. Adapun karya yang ditugaskan oleh dosen, dan disikapi mahasiswa dengan menciptakan karya yaitu karya trimatra berdasarkan unsur atau elemen desain. 


\section{Unsur/Elemen Desain}

Karya trimatra mahasiswa merupakan wujud nyata/tiga dimensi dari pembelajaran pengetahuan (aspek kognitif) tentang Nirmana. Karya merupakan pengorganisasian / penyusunan elemen desain dengan prinsip penyusunan desain meliputi kesatuan, keseimbangan, irama, komposisi, proporsi, pusat perhatian, keselarasan, gradasi dan penekanan. Karya mahsasiswa mulai dari elemen garis, bidang, bentuk. Mahasiswa juga diberikan kesempatan untuk ekplorasi terhadap garis, bidang maupun bentuk pada tugas kontruksi Nirmana dan eksplorasi tekstur. Eksplorasi ini berada pada level upaya meningkatkan kreativitas mahasiswa melalui persepsi visual setelah melalui tahap penyusunan elemen dasar. Selanjutnya karya mahasiswa ditelusuri kesesuaian dan relevansinya dengan teori Nirmana sebagai pengukuran daya serap mahasiswa dan sebagai bahan evaluasi karya. Pada tahap ini, pembelajaran praktik Nirmana II (Trimatra), mahasiswa ditekankan untuk memiliki kreativitas, untuk menemukan ide dan gagasan dengan ekplorasi dan diberikan kebebasan. Namun demikian, mahasiswa tetap menerima dan mempertimbangkan hasil koreksi, evaluasi dan saran dari dosen.

Memiliki kemampuan kreatif merupakan sebuah pilihan dan hak setiap orang. Berkaitan dengan hal tersebut, ada beberapa aspek penting yang mendukung mahasiswa untuk dapat menguasai materi pembelajaran Nirmana. Upaya pengkondisian keterampilan berfikir kreatif mahasiswa didukung oleh cara pembelajaran yang diberikan. Bila upaya pengkondisian keterampilan berfikir yang diberikan dosen kurang memberikan pencerahan bagi pengembangan nalar mahasiswa dan keterampilan berpikir yang baik, hal ini dapat mengakibatkan lemahnya pemahaman mahasiswa dalam Nirmana, sehingga capaian pembelajaran kurang optimal. Berdasarkan hal tersebut penting kiranya diberikan strategi yang dapat mendukung dalam optimalisasi kemampuan mahasiswa.

\section{Visualisasi}

Salah satu alternatif cara yang cukup mudah untuk membantu mahasiswa mendeskripsikan/memaparkan ide dan gagasan menuju ke dalam komposisi desain adalah dengan meminta mereka menutup mata dan membayangkan apapun yang akan diwujudkan menjadi objek desain. Sebuah pengaplikasian dari strategi ini melibatkan para mahasiswa menciptakan sendiri "kanvas batin" dalam mata pikiran mereka.

Melalui strategi visualisasi, mahasiswa merancang suatu komposisi dari unsur rupa dan desain berupa bentuk-bentuk tertentu yang diimajinasikan berdasarkan prinsip rupa dan desain. Suatu irama dan harmoni pada alam atau benda yang dibayangkan dalam pikiran. Sebagai contoh: merancang komposisi trimatra berdasarkan imaji terhadap suatu irama tangga rumah/bangunan atau gelombang laut, sehingga menghasilkan sebuah komposisi yang berirama dan dinamis, yang diwujudkan dalam komposisi tiga dimensi.

\section{Pendekatan Warna}

Warna merupakan bagian dari unsur rupa dan desain yang secara cepat dapat tertangkap oleh indra mata. Mahasiswa yang sangat spasial seringkali sensitif terhadap warna dan memahami pengelompokannya berdasarkan teori warna. Warna dapat digunakan untuk menekankan pola-pola tertentu dalam menata komposisi Nirmana trimatra. Mahasiswa mampu mempergunakan warna-warna berdasarkan pengetahuan 
teori warna yang pernah dipelajari (lingkaran warna) dalam mengkombinasikan bentuk dengan penerapan warna melalui sebuah komposisi desain yang dinamis dan seimbang.

Pada strategi ini, mahasiswa diberi tugas untuk merancang komposisi bidang trimatra berdasarkan nama teori warna tertentu, sehingga mampu menjelaskan warna apa yang mahasiswa terapkan. Kemampuan mengelompokkan warna dapat meningkatkan proses belajar mengajar. Lebih jauh lagi mahasiswa memahami makna pada setiap warna yang disajikan, serta pengaruh warna terhadap perasaan (dari indera mata, ke psikologi) warna menimbulkan pengaruh terhadap jiwa, misalnya perasaan gelisah, nyaman, panas, dan sebagainya. Warna menimbulkan kesan tertentu dalam menciptakan suasana ruang yang juga berkontribusi dalam mengasah kecerdasan spasial.

\section{Visualisasi dengan Gaya Metafora}

Metafora merupakan perbandingan antara dua hal yang tidak berhubungan, misalnya melibatkan perbandingan antara satu ide dengan ide lainnya, yang tampaknya tidak memiliki hubungan. Metafora gambar mengungkapkan konsep ini dalam sebuah gambar visual. "Seorang psikolog perkembangan menyatakan bahwa anak muda adalah master dari metafora" (Gardner dalam Armstrong, 2013: 88). Nilai pendidikan dari penggunaan metafora terletak pada pembangunan koneksi-koneksi antara apa yang mahasiswa ketahui, dan apa yang akan mereka presentasikan melalui sebuah desain. Contoh penerapan strategi ini misalnya dosen menjelaskan sesuatu dengan disertai ilustrasi gambar untuk membandingkan antara komposisi yang selaras dengan yang tidak selaras. Ilustrasi gambar tersebut diharapkan dapat memberi pemahaman lebih banyak pada mahasiswa sebagai bahan pembelajaran untuk memecahkan persoalan dalam penataan komposisi trimatra.

\section{Membuat Sketsa Ide}

Penerapan sketsa pada kuliah Nirmana II (Trimatra) tidak disamakan dengan sketsa bentuk produk, mengingat pemaknaan dari Nirmana tidak berbentuk dan tidak bermakna. Namun strategi ini lebih pengarahan pada mahasiswa untuk menggambar ide utama, tema utama, atau konsep inti yang akan diterapkan pada tugas komposisi/nirmana kontruksi sebuah karya. Kerapian dan realisme dapat ditekankan untuk mendukung keberhasilan membuat sketsa-sketsa cepat yang mampu membantu menyempurnakan ide. Strategi ini dapat digunakan untuk mengevaluasi pemahaman mahasiswa terhadap sebuah ide. Selain itu juga untuk menekankan sebuah konsep yang jelas dan memberikan banyak kesempatan kepada mahasiswa dalam mengeksplorasi ide secara mendalam.

\section{Simbol-simbol Gambar}

Pada strategi ini dosen cukup berperan aktif sebagai fasilitator dan ceramah sehubungan dengan teori pembelajaran Nirmana melalui simbol-simbol. Gambar yang disajikan dengan menggambar di papan tulis dan contoh gambar dalam bentuk slide power point. Sebagai contoh dengan membuat simbol-simbol gambar yang melukiskan konsepkonsep yang akan dipelajari. Dalam strategi ini, dosen menjelaskan sesuatu dengan disertai contoh berupa visualisasi gambar. Hal ini dimaksudkan agar mahasiswa lebih paham dan dapat membayangkan secara visual maksud dari materi yang disampaikan.

Kelima tahapan strategi pengajaran di atas merupakan upaya yang dilakukan dalam siklus II dalam pembelajaran untuk mengasah kecerdasan spasial mahasiswa agar 
kegiatan pembelajaran Nirmana lebih mudah dipahami, optimal dan sesuai dengan tujuan pembelajaran. Dengan memiliki kecerdasan spasial yang baik mahasiswa diharapkan mampu mengolah keterampilannya, menguasai proses berpikir kreatif sehingga mampu menghasilkan ide atau gagasan untuk menciptakan inovasi baik dalam karya Nirmana maupun sebagai pengantar pemahaman dalam seni rupa dan desain secara menyeluruh.

\section{Nirmana Trimatra dan Bentuknya}

Dalam desain grafis, Nirmana memegang peranan penting tentang bagaimana menata dan menyusun elemen dasar sebuah desain menjadi komposisi yang serasi dan seimbang. Nirmana merupakan pengorganisasian atau penyusunan unsur-unsur visual seperti titik, garis, bidang, warna, ruang, gelap, terang, dan tekstur menjadi satu kesatuan yang harmonis. Nirmana dapat juga diartikan sebagai hasil angan-angan dalam bentuk dwimatra dan trimatra yang mampu memiliki nilai keindahan. Nirmana terdiri dari dua jenis yaitu nirmana dua dimensi (dwimatra) dan nirmana tiga dimensi (trimatra). Nirmana dwimatra merupakan nirmana yang dibuat di atas bidang datar, memiliki panjang dan lebar. Fungsi nirmana dwimatra diantaranya melatih kepekaan estetis mahasiswa dalam mengelola unsur-unsur rupa seperti warna, bentuk, garis. Pada nirmana dwimatra terdapat berbagai pertimbangan dalam mengelola komposisi, irama, dan kesatuan pada bidang datar sehingga menjadi kesatuan yang harmoni dan selaras. Sedangkan nirmana trimatra dibuat di atas bidang yang mempunyai panjang, lebar, tinggi, dan memiliki ketebalan, ruang serta volume. Fungsi nirmana trimatra sama seperti nirmana dwimatra yaitu sama-sama melatih kepekaan estetis mahasiswa dan melatih kreativitas dalam mengolah unsur-unsur rupa yang berbentuk tiga dimensi. Perbedaannya dengan Nirmana dwimatra adalah karya nirmana trimatra dapat dinikmati dari berbagai sudut pandang secara serempak untuk mencapai keserasian rupa. Ada beberapa unsur rupa yang menjadi dasar terbentuknya sebuah karya nirmana diantaranya adalah titik, garis, bidang, bentuk, warna, dan tekstur. Unsur-unsur rupa tersebut dapat dikelola dalam penataan komposisi dengan memperhatikan prinsip-prinsip kesatuan, simetri, irama, keseimbangan, dan harmoni. Berikut ini adalah penjelasan mengenai penataan komposisi nirmana:

a. Kesatuan, merupakan paduan dari berbagai unsur rupa yang membentuk suatu konsep sehingga memberikan kesan sebuah bentuk yang utuh. Kesatuan atau keutuhan dapat dikatakan sebagai tujuan pencapaian desainer supaya hasil karya terlihat utuh dan terbilang menarik untuk dilihat. Salah satunya menjadikan unsur rupa menjadi lebih dominan. Unsur dominan tersebut dihasilkan dari pengulangan. Penekanan dan pengulangan merupakan hal sederhana untuk menciptakan keutuhan estetika yang biasa dilakukan oleh seniman maupun desainer yang bergelut pada aspek visual. 


\section{PRASI JURHLL BAHASA, SEN, DAN PENGAARANWYA}

VOL. 15 | No. 01 | Juni 2020

ISSN: Print 1693-6124 - Online 2614-1116

Undiksha| DOI: http://dx.doi.org/10.23887/prasi.v15i01.24118 | https://ejournal.undiksha.ac.id/index.php/PRASI

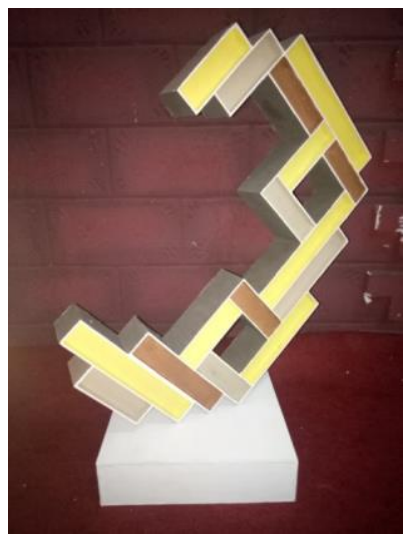

Gambar 1. Kontruksi kesatuan bidang, gempal dan warna

b. Simetri, menggambarkan dua atau lebih unsur yang sama dalam suatu susunan yang diletakkan sejajar atau unsur-unsur di bagian kiri sama dengan bagian kanan.

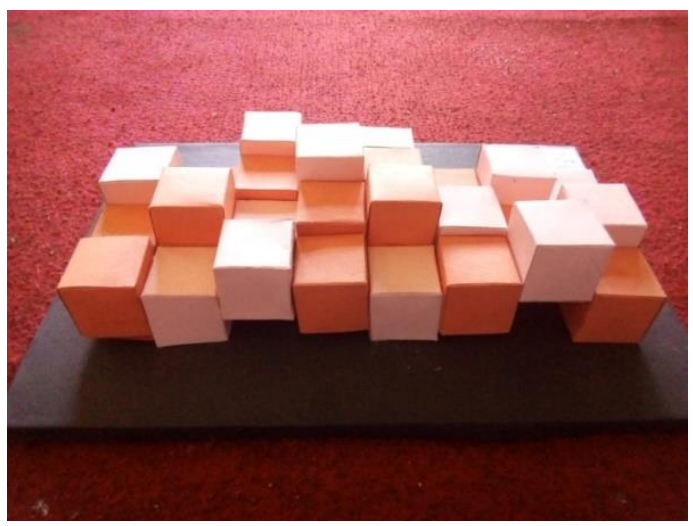

Gambar 2. Penyusunan bangun ruang kubus dengan prinsip persamaan.

c. Irama, merupakan suatu pengulangan unsur-unsur rupa secara berulang, terus menerus, teratur, dan dinamis. Irama pengulangan namun bersifat bergerak, baik secara repetisi, silih berganti, progresi, maupun regresi. Keempat jenis irama tersebut memiliki arah turunan masing-masing, tegantung kreativitas pengembangan yang dilakukan perupa.

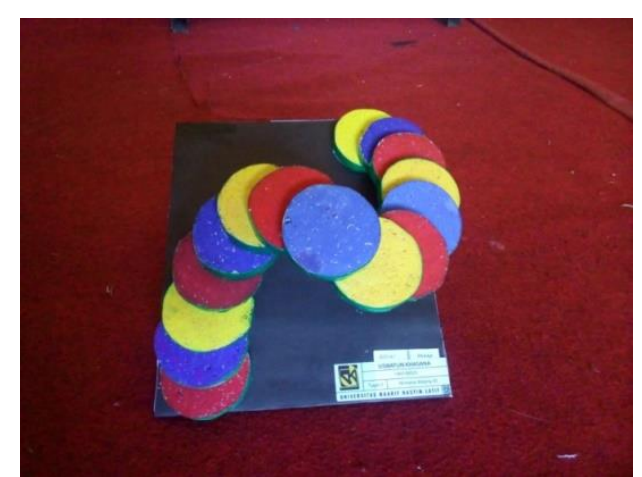

Gambar 3. Irama dengan repetisi bentuk, penerapan warna primer.

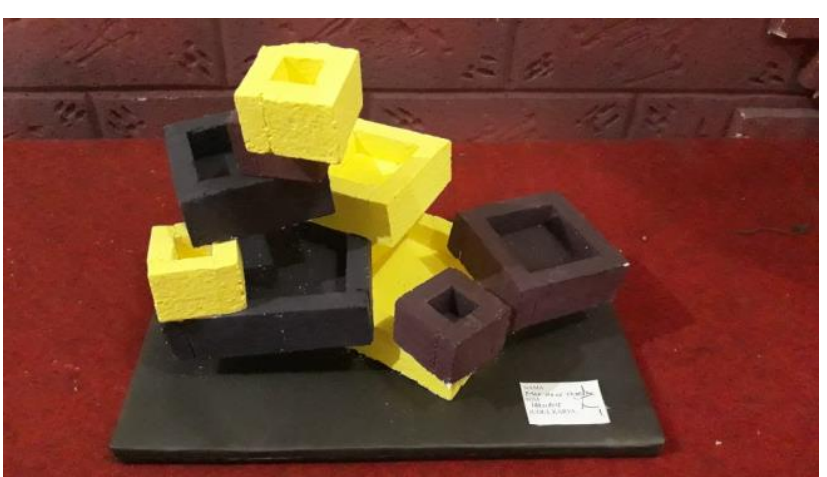

Gambar 4. Irama dengan gerak silih berganti. 
d. Keseimbangan, merupakan penempatan unsur-unsur rupa dalam suatu bidang baik secara teratur maupun acak. Keseimbangan dapat diwujudkan melalui penyusunan unsur rupa yang simetris dan asimetris. Keseimbangan memberikan tekanan pada stabilitas.

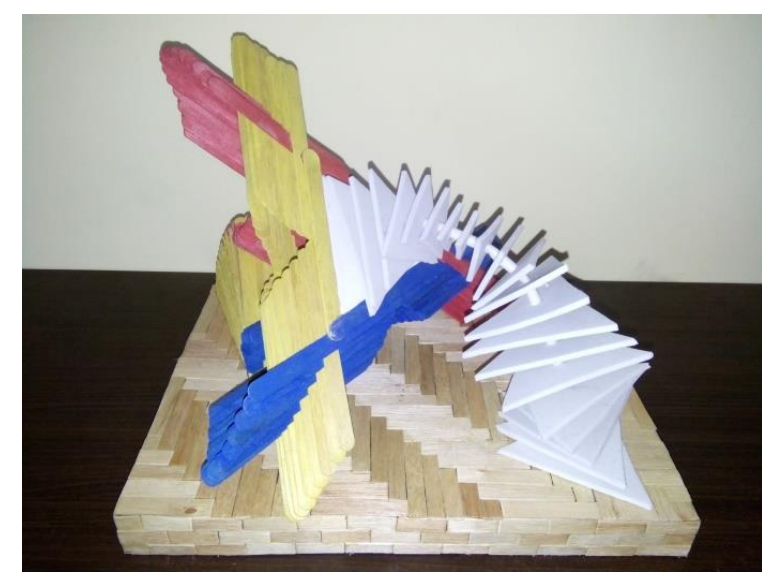

Gambar 5. Penyusunan unsur bidang dengan prinsip keseimbangan asimetris

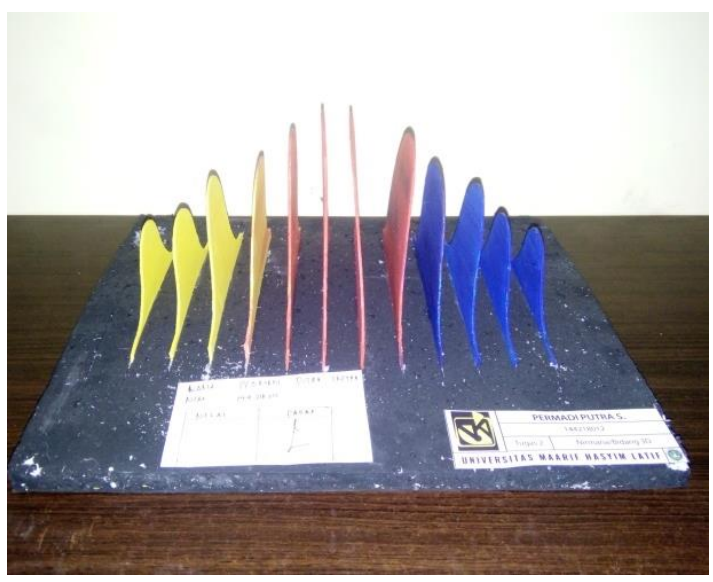

Gambar 6. Oposisi ukuran, arah, warna, arah, gerak dengan prinsip keseimbangan simetris

e. Harmoni, merupakan keselarasan paduan unsur-unsur rupa yang berdampingan, sedangkan hal yang sebaliknya atau bertentangan disebut kontras. Harmoni terbentuk karena adanya unsur keseimbangan, keteraturan, kesatuan, dan keterpaduan yang masing-masing saling mengisi.

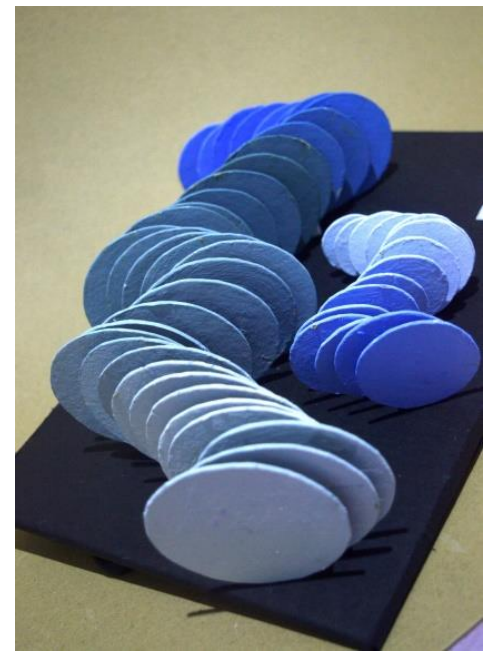

Gambar 7. Pengorganisasian bidang dengan memperhatikan keteraturan bentuk dan gradasi warna primer biru sebagai bagian dari harmoni.

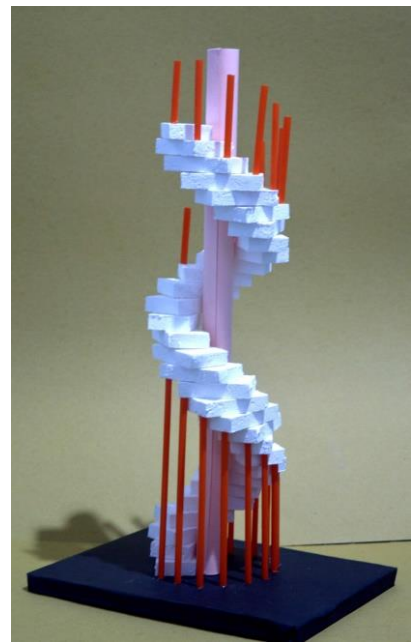

Gambar 8. Konstruksi kombinasi unsur garis dan bidang dengan menekankan keseimbangan, keteraturan, kesatuan, dan keterpaduan.

\section{Evaluasi Pembelajaran}

Evaluasi bagian dari tindakan yang tidak bisa diabaikan dalam proses pembelajaran. Hal ini dilaksanakan guna mengetahui sejauhmana daya serap mahasiswa 
terhadap mata kuliah Nirmana II, sehingga dosen mengetahui seberapa jauh ketercapaian yang sesuai dengan tujuan pembelajaran. Pada evaluasi ini, penilaian mencakup karya trimatra dan kemampuan mempresentasikan karya yang disajikan baik dalam bentuk power point maupun bentuk tulisan pada laporan karya. Selain itu sebagai penutupan akhir semester diadakan kegiatan pameran karya, sebagai bagian dari akumulasi penilaian akhir pada mata kuliah Nirmana II (Trimatra). Hasil nilai akhir yang diperoleh oleh mahasiswa merupakan hasil dari akumulasi instrumen penilaian yang telah ditentukan.

\section{SIMPULAN}

Terjadinya perubahan proses pembelajaran adalah sesuatu yang wajar dalam rangka meningkatkan kualitas pendidikan bagi mahasiswa Prodi Desain Komunikasi Visual, Universitas Maarif Hasyim Latif. Sebagai program studi baru, Prodi Desain Komunikasi Visual perlu melakukan berbagai penyesuaian termasuk pada mata kuliah Nirmana II (Trimatra). Mata kuliah ini perlu disesuaikan dengan karakteristik, kebutuhan serta visi dan misi Program Studi Desain Komunikasi Visual yang tercantum dalam kurikulum.

Nirmana II (Trimatra) sebagai mata kuliah yang bersifat wajib ditempuh dalam disiplin ilmu seni rupa dan desain, terdapat kesesuaian dan relevansi guna meningkatkan kreativitas dalam berkarya. Strategi memahami dan menguasai Nirmana II melalui pendekatan kecerdasan spasial mampu menambah wawasan dalam aspek keilmuan, praktik karya dan meningkatkan daya apresiasi. Dalam memahami Nirmana II, kecerdasan spasial merupakan hal yang menunjang pengembangan kreativitas mahasiswa dalam melahirkan ide dan gagasan. Hal ini dikarenakan kecerdasan spasial berkaitan dengan hal-hal visual termasuk desain yang menyangkut ruang, bentuk, dan warna. Prodi Desain Komunikasi Visual erat hubungannya dengan komunikasi dan persepsi visual, sehingga Nirmana II sebagai akar dan pijakan mampu memberikan solusi bagaimana melatih proses berpikir kreatif mahasiswa melalui strategi pembelajaran dengan kecerdasan spasial-visual sebagai calon desainer. Meskipun demikian, perbaikan dalam kurikulum dan proses pembelajaran masih tetap perlu untuk dilakukan, khususnya pada mata kuliah wajib yang berhubungan dengan Program Studi Desain Komunikasi Visual seperti penguatan dalam bidang keilmuan seni rupa dan desain serta peningkatan mutu melalui kreativitas mahasiswa dalam citra visual. Adapun prosedur atau langkah yang diambil oleh dosen guna perubahan pembelajaran yang optimal sehingga ada perbaikan kualitas dengan perlakuan metode ceramah guna meningkatkan kemampuan pengetahuan (kognitif) mahasiswa, metode diskusi dengan pembagian kelompok fokus pada pendalaman teori, dan analisis karya. Sementara metode dengan porsi yang diutamakan yaitu metode praktik Nirmana II berbasis kontekstual dengan titik poin berkarya dan berkreasi berdasarkan konsep keilmuan.

\section{DAFTAR PUSTAKA}

Armstrong, Thomas. 2013. Kecerdasan Multipel di dalam Kelas. Jakarta: PT Indeks.

Lester, P. M. 2006. Visual Communication: Images with Message. Toronto: Thomson Wadsworth Publishing. 
Munir. 2008. Kurikulum Berbasis Teknologi Informasi dan Komunikasi. Bandung: Alfabeta

Santoso, S. 2000. Problematik Pendidikan dan Cara Pemecahannya. Jakarta: Kreasi Pena Gading

Sudarma, Momon. 2013. Mengembangkan Keterampilan Berpikir Kreatif. Jakarta: PT Raja Grafindo Persada. 